\title{
Developing Project-BaSed Learning Related to Local WiSdoM in IMPROVING STUdENTS' Problem-SolVING SKILlS
}

\author{
Rita Retnowati ${ }^{1)}$, Rita Istiana ${ }^{1)}$, Nadiroh $^{2)}$ \\ ${ }^{1)}$ Pakuan University, Bogor, Indonesia \\ ${ }^{2)}$ State University of Jakarta, Jakarta, Indonesia \\ E-mail: rita_istiana@unpak.ac.id
}

\begin{abstract}
The purpose of this research is to determine the effectiveness of the development of the Project-Based Learning (PjBL) model based on local wisdom in solving environmental problems and the students' ability to develop learning media. Research conducted at Educational Faculty and teaching sciences of Pakuan University. This research uses the method of Research and Development with the ADDIE model, comprising analyses, design, development, implementation, and evaluation. The data were obtained from the validation by three experts, namely learning material expert, learning media expert, and learning model expert. The effectiveness assessment was done by N-Gain assessment environmental problem-solving ability and evaluating the multimedia product. The steps to develop the model are as follows: need analysis, designing learning model development, learning model development, learning model validation by the experts, learning model implementation in class, and model evaluation. The product created by the students from learning through PjBL based on local wisdom is a video about local wisdom. According to the data analysis result, it can be concluded that model development of PjBL based on local wisdom improves their ability to solve environmental problems, the average score is 0.69 in experiment class and the score in control class is 0.055 (scales of 0-1.0). The ability to develop video environmental learning media the score video product in experiment class is 2.4 and in the control class is 2.2 (scales of 1-3).
\end{abstract}

Keywords: Project-Based Learning; Local Wisdom; Problem-Solving Skills

\section{INTRODUCTION}

Living environmental problems nowadays are the problems that most often happen in the Indonesian environment. These problems are caused by many factors, both from environmental factors and human factors themselves. Most of these problems sometimes do not have the proper solutions yet to overcome them, hence the destructions to nature and the environment continue to happen (Reza, 2017) This is because nature is the source to fulfill all the needs to support human lives, such as the availability of water, air, food, medicines, aesthetics as well as the materials for dwellings.

The environmental problem that is found in daily life is environmental pollution. Air, land and water, and also sound pollutions require a long time to return to normal conditions. The industrial sectors and vehicle exhausts are the main sources of air pollution. On the other hand, heavy metals, nitrate, factory waste, household waste also pollute the waters including lakes, rivers as well as seas (Yu, Yang, \& $\mathrm{Li}, 2019$ ).
Climate change also becomes one global problem that involves the roles of many stakeholders because it affects many sectors and can threaten the survival continuity of all beings on earth. Climate change is the change of the climate components in a long period (50 to 100 years) that is influenced by human activities that result in greenhouse gas emissions (Rosidin \& Suyatna, 2017). A lot of human activities contribute to climate change to happen, for example, industrialization, transportation, forest fires, deforestation, and many others (Diposaptono \& Budiman, 2009).

The continuous greenhouse gas emission (GGE) creates a massive and global impact. IPCC (2007) states that the amount of greenhouse gas emission at the moment increases up to twice as much. Three main GGEs, namely Carbondiocside $\left(\mathrm{CO}_{2}\right)$, Methane $\left(\mathrm{CH}_{4}\right)$, and Nitrogen Oxide $\left(\mathrm{N}_{2} \mathrm{O}\right)$. The three of them have a lifetime of 10 to 200 years and of the three the most rapid increase in $\mathrm{CO}_{2}$ gas (Setiawan, 2014). In the case of Indonesia, the biggest source of GGE is the conversion of peatland/area the shift of the use of forest to other land uses. The National Body for 
Climate Change predicts that the GGE in Indonesia will experience an increase of up to 5.1 percent in the year 2013 (Taufik \& Izdihar, 2017).

It is the non environmentally friendly human activities that result in degrading air quality. Polluted air can give serious effects on human health, creates smoke and cause acid rain, reduce cultivation production due to disturbed growth of the crops, decrease the protecting power of the ozone layer in the atmosphere that can eventually change the global climate (Liang \& Yang, 2018). The characteristics of air make the effects of air pollution to be direct locally, regionally as well as globally.

Environmental problems are not the problem of a certain country only, it has become the responsibility of all countries in the world. That's why various efforts to prevent more serious damage to the living environment have been done. One of the ways that can reduce environmental damage is through instilling the awareness, care, and understanding of the people about the environment through environmental education (Wihardjo et al., 2017).

Environmental education plays an important role in solving environmental damages and becomes an important media in creating human resources that can carry out the principles of continuous development. As put forward by Retnowati, Istiana, and Suhardi (2018) that at the moment they need for environmental education is very critical. Environmental education is conducted as an effort to improve the understanding and care of the society in searching for the solution to and prevention of environmental problems occurrence (Bramasta, 2018).

Environmental education needs to be given as early as possible because to develop a positive attitude towards the environment needs a long time. According to Sutrisno (2005), introducing nature to children early is an initial step for them to value/respect nature. Knowing nature directly in the field will trigger the children to know more about it and the lives inside it. By knowing nature well, they will care for and love their environment (Buldur \& Omero, 2018). For that reason, environmental education should be introduced as early as possible so that in the future the damage to the environment that has been done to it now can be minimized. Consequently, environmental education can be one solution to overcome environmental issues.

To build a degree of understanding about the balanced environment with the active role of the people in the development processes, continuous education related to environmental conservation issues should be given (Clark, 2012). Education can be formally given through educational institutions or informally in society.

In the educational world, there are a lot of education methods about the environment. To improve their problemsolving skills related to environmental problems, the students should be taught by utilizing creative and innovative learning methods to catch their attention and be interested in learning more about their environmental problems. The learning will be successful if the students are involved to interact actively with the object and process of learning through the process of direct observation in the field
(Astina, 2017). Based on the observation results, the students later can construct their knowledge themselves. A learning approach like that is the constructivism approach (Retnowati \& Helena, 2018). One of the learning methods belonging to constructivism is Project-Based Learning. According to Retnowati, project-based learning is a learning activity that involves the students in problem-solving activities and allows them to autonomously construct their learning and eventually creates a working product that is realistic (Retnowati \& Helena, 2018).

Alberto, Goncalves, and Hess (2015) state that projectbased learning is effective learning in facing the present challenges. Project-based learning is also the main facility to prepare a learning experience as a way to reflect professional practices (Hanney, 2018). According to Fugate (2018), project-based learning is a modern learning method whose core is the learning that relates students' experience with their school experience and can trigger serious thoughts when the students get new experiences. Through projectbased learning, the connection of the students to the real world can be achieved. This learning method is viewed as an approach that enables the students to develop "the twentyfirst-century skills" that are cognitive and socioemotional skills required to achieve success in college and career (Quint \& Condliffe, 2018).

Alberto, Goncalves, and Hess (2015) stated that learning in college is defined as an active understanding process and involves meaning and skills that are following project-based learning. For teacher-to-be students, the experience to join this learning method is very important to get direct experience related to developing educational projects. The use of project-based learning in the current environmental material is less relevant in the environment. Learning environmental material was still mostly done in classrooms or laboratories, this results in students being less able to solve the environmental problem in their environment.

Local wisdom can be comprehended as local ideas that are characterized by wisdom, has a positive value, that is rooted and followed by the society's members. Furthermore, Istiawati (2016) had a view that local wisdom is the way how people view and behave as a response to the changes in the physical and cultural environment. A conceptual idea that lives in the society, grows and develops continually in the awareness of the society from what is related to sacred lives up to what is profane (parts of the daily life that are just common practices). Local wisdom can be understood as local thoughts that are wise and have the good value that is rooted in the society and are followed by its members (Anggraeni, (2017).

Project-based learning that is combined with local wisdom can result in meaningful learning for the students. The project-based learning that is creative and innovative requires the students to build "the bridge" that makes connections among various material objects. The making of video learning media that is related to environmental damages in the areas where the students live will be more suitable because it is contextual. The video media is made in groups. The final product in the form of a film about 
environmental damages later is presented in the class. The plus points in the process of film making and the film produced will make the students interested in learning about the environment and its conservation. The project-based learning through film making will activate the psychomotor and affective aspects of the students. Meanwhile, the local wisdom will create a way of thinking that will help to guide the students to be creative in overcoming the environmental issues.

Based on the theories and results of the research above, it is essential to develop project-based learning featuring local wisdom in improving the students' problem-solving skills and also to improve their ability to develop a video learning media about the environment for Biology teacher-to-be students. The purpose of this research is to find out the effectiveness of model development of Project-Based Learning $(\mathrm{PjBL})$ featuring local wisdom in improving the environmental problem-solving skills and also the ability to develop learning media of the students of Educational Biology students, Faculty of Teacher Training and Educational Sciences, Pakuan University.

\section{Methodology}

The making process of Project-based Learning based on local wisdom for the subject matter of Environmental Sciences and Bioconservation altogether goes through several research stages. Needs and condition analysis were focused on the real condition of the subject of Environmental Sciences Bioconservation at the Major Study of Educational Biology, Faculty of Teacher Training and Educational Sciences, Pakuan University. Hence, the subject matter requires a breakthrough that is related to educating the students with higher thinking skills which among others is the ability to solve environmental problems. The present learning processes do not take into considerations that aspect adequately. Project-based learning is expected to be able to improve their high order thinking skills and also able to improve their abilities in developing learning media. Educational biology students as prospective teachers are expected to be skillful in developing learning media and also possess local wisdom that is related to the environment where they live so that they will have concerns and can solve the environmental problems that are present around them.

The first step is literature study and observation whose aims are to collect information and theories related to the problems to study, especially about the general view of the environmental issues in Bogor municipality and Bogor District. The second step is developing the learning model that requires the students to be able to make a product so that they can be creative in developing learning media related to the environment and local wisdom of Bogor. The third step is testing the model's effectiveness in improving the students' skills to solve environmental problems.

\section{A. Literature and Feasibility Study}

A literature study is one source of knowledge for the research that is done through studying the latest literature related to the learning model, the literature about local wisdom, and the literature related to learning media. Besides literature study feasibility study is also conducted through several educational experts (educational practitioners and academicians) who are closely related to Project-based Learning featuring local wisdom, and also the environmental experts especially the living environment in Bogor municipality and district.

\section{B. Data Collection}

Field observation is needed a lot to collect the information and pictures related to local wisdom in Bogor, especially the local wisdom related to the living environment.

\section{Model Design}

The designing technic applied was the ADDIE model. ADDIE is the abbreviation of Analysis, Design, Development or Production, Implementation or Delivery, and Evaluation. ADDIE model was chosen. After all, it is considered to be flexible because it can be used in developing various kinds of products, for instance, learning models, learning strategies, learning methods, learning material, and learning media. This model was developed by Dick, Carey, and Carey (2015) to design a learning system.

The following is the ADDIE model:

1. Analysis

This stage is the analysis stage on the need to develop a new learning model namely project-based learning based on local wisdom. At this stage, it was analyzed whether the model, media, and technology utilized were feasible to be applied by the lecturers and the students. This stage was very crucial because it became the foundation for the development of the new learning model.

2. Design

At this stage, the learning method design was developed and it was done systematically starting from deciding the learning objectives, designing the learning tools, and also completing the materials and making the evaluation tools.

3. Development

The development stage was done after the stages of analysis and design were completed. This stage was started with the development of a learning model based on the project, the development of evaluation tools, and the development of product design. The product in this research is video learning media that is based on local wisdom in Bogor.

4. Implementation

At this stage was the application of the model in the class that had been designed before, starting from giving the materials, giving guidance about the project task, presenting the project, and designing the project in the form of video media based on local wisdom. After the learning-teaching process was finished evaluation was conducted and the lecturers and the students were asked to give feedback for the model improvement.

5. Evaluation

The evaluation was the last stage at the end of this model development, and it was in the form of a formative or 
summative test. The next stage was revising the weaknesses that were obtained during the evaluation process. At this stage, the model effectiveness was carried out, namely assessing the ability to solve the environmental problem and the ability to develop environmental learning videos.

\section{RESULTS AND DISCUSSION}

The results of the learning model development PjBL based on local wisdom utilizing the ADDIE model are as follows:

\section{A. Analysis}

Based on the information obtained from the initial data analysis results of the research and also based on the literature it is found out that project-based learning is suitable for the learning of adult people. This research was done on college students that are categorized as an adult. According to Retnowati and Helena (2018), project-based learning can improve the higher order of thinking skills which among others is the ability to solve environmental problems. According to Yoo and Park (2014), the learning done by observing the cases in the field can stimulate students' ability to solve problems.

Tripodi (2018) stated that learning that uses and develops video media can successfully improve the higher-order thinking of the students. In project-based learning, by solving various problems it is made possible for the students to develop creative ideas while at the same time improve their skills (Sart, 2014).

Field observation was done to the lecturer of subject matter Environmental Sciences and Bioconservation, facilities, infrastructures, and students' characteristics to find out the condition and needs in the field. From the observation, it was discovered that the use of the $\mathrm{PjBL}$ model featuring local wisdom is feasible to be done for the subject matter. This is because the learning model is really suitable with the characteristics of the subject matter and also suitable with the learning objective to be achieved that is the ability to solve environmental problems and the ability in developing the video learning media. The combination of literature study and field observation results in a model draft of project-based learning based on local wisdom for the students who join the subject matter Environmental Sciences and Bioconservation.

\section{B. Design}

Design is the second stage in the design model of the learning system ADDIE. At this step, there should be learning program clarification that is designed so that the program can reach the learning objective as expected. The design stage produces a learning model draft, which later will be validated by a learning model expert, multimedia expert, and the expert of environmental problem learning materials (Table I).
TABLE I

EVALUATION RESUlt OF MODEL DRAFT BY EXPERT

\begin{tabular}{|c|c|c|}
\hline No. & Expert & Input \\
\hline 1. & $\begin{array}{l}\text { Environmental } \\
\text { Problems Materials }\end{array}$ & $\begin{array}{l}\text { 1. Elaboration of the } \\
\text { materials are adequately } \\
\text { complete and comprehensive, } \\
\text { however, there should be a } \\
\text { correction to the choice of } \\
\text { the environmental issue to be } \\
\text { taken in making the project. } \\
\text { 2. An instrument that can } \\
\text { measure creativity in } \\
\text { developing learning media } \\
\text { following the indicator } \\
\text { should be developed. }\end{array}$ \\
\hline 2. & Learning Model & $\begin{array}{l}\text { 1. Syntax/the steps of the } \\
\text { PjBL model based on local } \\
\text { wisdom should be made } \\
\text { more effective. } \\
\text { 2. The use of learning media } \\
\text { should be made more varied. } \\
\text { 3. Time allocation should be } \\
\text { reviewed so that it conforms } \\
\text { with the syllabus. } \\
\text { 4. The schedule to plan the } \\
\text { making of video media } \\
\text { should be optimized to } \\
\text { facilitate the project making. }\end{array}$ \\
\hline 3. & Multimedia & $\begin{array}{l}\text { 1. The worksheet for the } \\
\text { making of video media } \\
\text { should be made clearer by } \\
\text { utilizing the concept map. } \\
2 \text {. The concept of local } \\
\text { wisdom in the making of } \\
\text { video media should be made } \\
\text { clearer by informing the } \\
\text { location the video was shot. }\end{array}$ \\
\hline
\end{tabular}

\section{Development}

The developed project-based learning model based on local wisdom is one of the learning models based on projects that give opportunities to the students to work in groups and give opportunities to the lecturers to manage the learning processes in a class by picking up project work with the theme of local wisdom in Bogor. The project work by making learning film or video that feature local wisdom about conservation efforts of the natural resources based on the questions and issues of natural resources in Bogor at present, which also requires the students to design, solve problems, make decisions by conducting investigation activities in the field (Fig. 1).

\section{Implementation}

Implementation is the third stage carrying out the ADDIE model, implementation step covers the activities to try out the model draft that has been made and has been validated by the learning experts directly. From the implementation results, feedbacks from the lecturer and students are obtained concerning the application of PjBL based on local wisdom. 
The feedback from the lecturer after the learning process is completed can be seen in Table II.

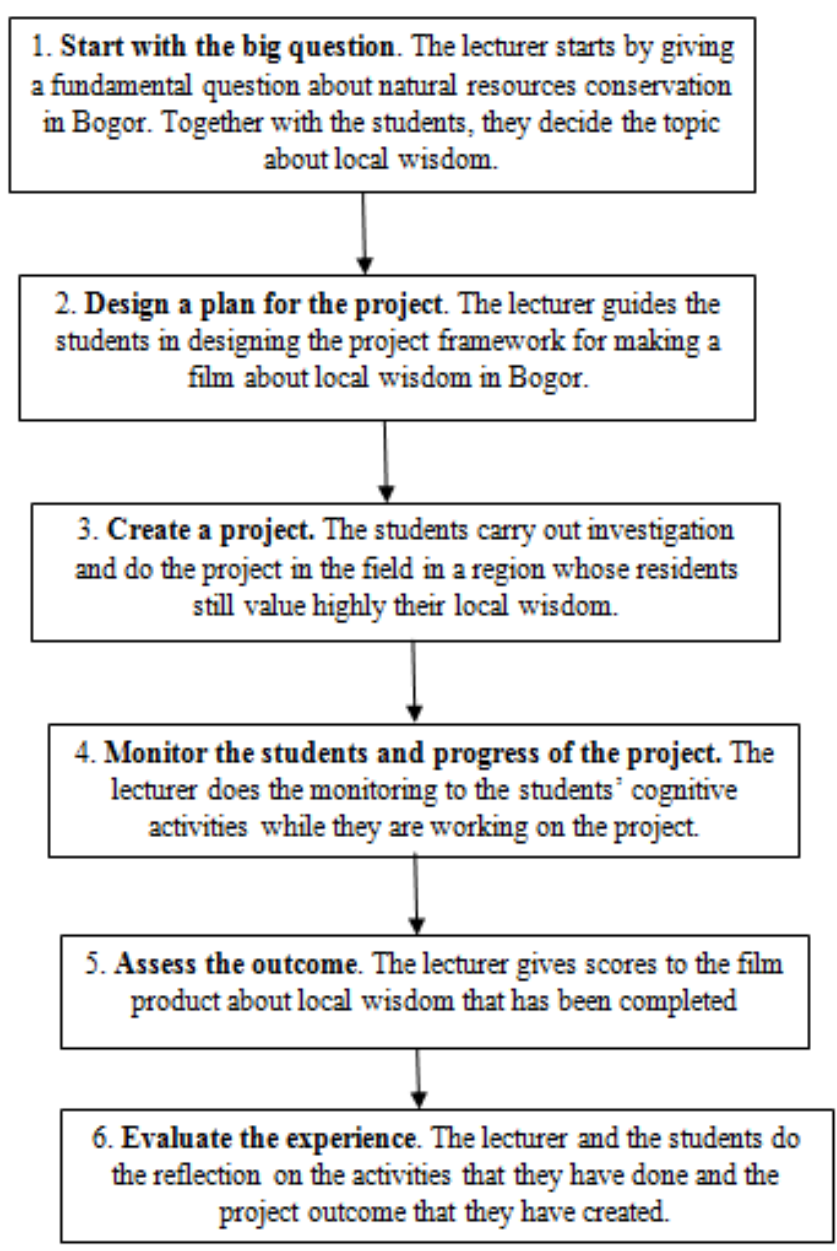

Fig. 1 Conceptual model of the learning model PjBL based on local wisdom

The lecturer's response shows that the PjBL method based on local wisdom has a very good effect in improving the motivation, activeness, and creativity of the students in developing environmental learning media. This result is following the research result of Hanney (2018) that stated that project-based learning enables the students to get involved in analyzing a certain project and looking for solutions to the problems being faced. The proposed project has problems that are related to the conditions of the surrounding environment.

Besides the positive response shown in the lecturer's judgment, the students also show a similar response, they consider the PjBL method based on local wisdom can improve students' skills in creating something. The data from the students' responses in participating in the PjBL method based on local wisdom can be seen in Table III.
TABLE II

LECTURER'S RESPONSES AFTER THE IMPLEMENTATION OF PJBL METHOD BASED ON LOCAL WISDOM

\begin{tabular}{|c|c|c|c|}
\hline No & Question & Yes & No \\
\hline 1 & $\begin{array}{l}\text { Is the } \mathrm{PjBL} \text { model based on } \\
\text { local wisdom easier to } \\
\text { comprehend by the students? }\end{array}$ & $\mathrm{V}$ & \\
\hline 2 & $\begin{array}{l}\text { Can the PjBL model based on } \\
\text { local wisdom improve } \\
\text { students' creativity? }\end{array}$ & V & \\
\hline 3 & $\begin{array}{l}\text { Can the PjBL model based on } \\
\text { local wisdom improve } \\
\text { students' collaboration among } \\
\text { themselves? }\end{array}$ & V & \\
\hline 4 & $\begin{array}{l}\text { Can the PjBL model based on } \\
\text { local wisdom make the } \\
\text { students more active in their } \\
\text { learning? }\end{array}$ & V & \\
\hline 5 & $\begin{array}{l}\text { Can the PjBL model based on } \\
\text { local wisdom make the } \\
\text { students more active in their } \\
\text { learning? }\end{array}$ & V & \\
\hline 6 & $\begin{array}{l}\text { Is the PjBL model based on } \\
\text { local wisdom successful in } \\
\text { improving the students' } \\
\text { understanding of natural } \\
\text { resources? }\end{array}$ & V & \\
\hline 7 & $\begin{array}{l}\text { Is the PjBL model successful } \\
\text { in improving } \\
\text { creativity in developing } \\
\text { environmental } \\
\text { media? }\end{array}$ & V & \\
\hline
\end{tabular}

TABLE III

DAta of Students' ResPonse In JOINING LEARning Method PJBL BASED ON LOCAL WISDOM

\begin{tabular}{|c|c|c|}
\hline No & Question & Percentage $(\%)$ \\
\hline 1 & $\begin{array}{l}\text { In general, the way the lecturer gives } \\
\text { lectures is different from what it was } \\
\text { before. }\end{array}$ & 98 \\
\hline 2 & $\begin{array}{l}\text { I am more interested in learning } \\
\text { activities outside by directly doing } \\
\text { observation in the field. }\end{array}$ & 90 \\
\hline 3 & $\begin{array}{l}\text { I am more motivated by the way the } \\
\text { lecturer gives lectures by connecting } \\
\text { the materials with the environment in } \\
\text { Bogor. }\end{array}$ & 100 \\
\hline 4 & $\begin{array}{l}\text { I gain more knowledge from the } \\
\text { learning that is connected to the } \\
\text { phenomena in daily life. }\end{array}$ & 95 \\
\hline 5 & $\begin{array}{l}\text { I can understand the materials better } \\
\text { by the way the lecturer teaches. }\end{array}$ & 96 \\
\hline 6 & I am burdened by field observation. & 23 \\
\hline 7 & $\begin{array}{l}\text { Learning to make a film stimulate my } \\
\text { creativity }\end{array}$ & 100 \\
\hline 8 & $\begin{array}{l}\text { I am reluctant to cooperate with my } \\
\text { friends when I shoot the video in the } \\
\text { field. }\end{array}$ & 15 \\
\hline 9 & $\begin{array}{l}\text { Field observation can nurture my care } \\
\text { towards the environment. }\end{array}$ & 92 \\
\hline 10 & $\begin{array}{l}\text { A learning method like this model } \\
\text { can stimulate ideas to solve daily } \\
\text { problems. }\end{array}$ & 97 \\
\hline
\end{tabular}


Based on the data above it can be seen that the PjBL method based on local wisdom can improve problem-solving skills related to the environment and the ability to develop environmental learning media. This is in line with the research result of Tripodi, (2018) that says learning to utilize and developing video media successfully improves the higher-order thinking skills of the students, including the skills to solve environmental problems. Besides that, from Sart's research (2014) it is found out that the use of projectbased learning, by solving various problems enables the students to develop creative ideas while at the same time improving their skills.

\section{E. Evaluation}

The final stage of the model design of learning system ADDIE is evaluation, which is a process that is done to give values/scores to the development of a learning model that has been tried out in the field. The evaluation stage that is conducted in research is to find out whether the development of the learning model PjBL based on local wisdom can improve the problem-solving skills related to the environmental problems and the ability to develop video learning media. The assessment done of the video product that was created by the students covers the stages of preparation, production, the final stage, and cooperation (Table IV).

TABLE IV

ASSESSMENT OF LEARNING Video PRODUCT BASED ON LOCAL Wisdom IN MODEL Class

\begin{tabular}{|c|c|c|c|c|c|c|c|c|c|c|c|c|c|c|}
\hline \multirow[t]{2}{*}{ No } & \multirow[t]{2}{*}{ Assessment } & \multirow[t]{2}{*}{ Measured criteria } & \multicolumn{3}{|c|}{ Group 1} & \multicolumn{3}{|c|}{ Group 2} & \multicolumn{3}{|c|}{ Group 3} & \multicolumn{3}{|c|}{ Group 4} \\
\hline & & & 1 & 2 & 3 & 1 & 2 & 3 & 1 & 2 & 3 & 1 & 2 & 3 \\
\hline 1 & $\begin{array}{l}\text { Preparation } \\
\text { Stage }\end{array}$ & $\begin{array}{ll}\text { - } & \text { Carefulness in } \\
\text { preparing tools and } \\
\text { materials } \\
\text { - } & \text { Skillful in planning } \\
\text { - Creative in } & \text { developing ideas } \\
\end{array}$ & & & & & & & & & & & & \\
\hline 2 & $\begin{array}{l}\text { Production } \\
\text { stage }\end{array}$ & $\begin{array}{l}\text { - Skillful in using the } \\
\text { tools/camera } \\
\text { - Skillful in work } \\
\text { technics }\end{array}$ & & & & & & & & & & & & \\
\hline 3 & Final Stage & $\begin{array}{l}\text { - The resulted product } \\
\text { shows high esthetics } \\
\text { (picture and sound } \\
\text { quality) } \\
\text { - The final product } \\
\text { possesses essential } \\
\text { information } \\
\text { according to the } \\
\text { theme. } \\
\text { Skillful in } \\
\text { evaluating } \\
\text { outcome work }\end{array}$ & & & & & & & & & & & & \\
\hline 4 & Cooperation & $\begin{array}{llr}\text { - Good cooperation } \\
\text { (solidity) among } \\
\text { members } \\
\text { - Equal Workload } \\
\text { distribution } \\
\end{array}$ & & & & & & & & & & & & \\
\hline
\end{tabular}

Based on the assessment results, the average score for the product in the experiment class is 2.4 while the average score for the model control class is 2.2 (scales of 1-3). The assessment results show that the video product has been in line with what is expected from the learning process. This is following the opinion of Alberto, Goncalves, and Hess (2015) that the learning model of PjBL has been proved to improve the creativity and skill of the students in creating the products or works.

Besides the assessment of the video product, the students' ability in solving problems related to the environment is also assessed. The N Gain score on students' problem-solving skills related to the environmental issues for the experiment class is 0.69 , while the $\mathrm{N}$ Gain for the control class is 0.055 (scales 0-1). Both of the results above show that the implementation of the learning model PjBL based on local wisdom is effective in improving the problem-solving skills related to the environment of the students. This is following the research result of Troyer et al. (2012) that the learning model PjBL is a learning model based on problems that can improve students' problem-solving skills.

\section{CONCLUSIONS}

Based on the research and learning model development of PjBL based on local wisdom that implements ADDIE model, it can be concluded that the developed learning model $\mathrm{PjBL}$ based on local wisdom can be categorized as effective in improving students' skills in developing environmental learning media and their problem-solving skills related to 
environmental problems. Improves their ability to solve environmental problems, the average score is 0.69 in experiment class and the score in control class is 0.055 (scales of 0-1.0). The ability to develop video environmental learning media the score video product in experiment class is 2.4 and in the control class is 2.2 (scales of 1-3). This is crucial because the students of educational biology major as prospective teachers need to have experience in developing learning media so that they can motivate their students in the future to study further the learning materials that are well delivered.

\section{ACKNOWLEDGMENT}

The researchers would like to thank the Post Graduate Program of Pakuan University and LPPM Pakuan University who have provided them with research funds.

\section{REFERENCES}

Alberto, J., Gonçalves, P., \& Hess, A. (2015). Creating a Project-Based Learning Environment to Improve Project Management Skills of Graduate Students. $3(2), 120-130$.

Anggraeni, P. (2017). Character and Local Wisdom-Based Instructional Model of Bahasa Indonesia in Vocational High Schools, 8(5), 23-29.

Astina, I. K. (2017). Implementation of Project-Based Learning (PjBL) through One Man One Tree to Improve Students, Attitude and Behavior to Support Sekolah Adiwiyata, 10(3), 134-141. https://doi.org/10.5539/ies.v10n3p134

Bramasta, D. (2018). Implementasi Pendidikan Lingkungan dalam Menumbuhkan Sikap Peduli Lingkungan Peserta Didik. Seminar Nasional Prodi PGSD FKIP-UNMUH Purwokerto, 117-126. Retrieved from

https://digilib.ump.ac.id/files/disk1/44/jhptumpump-gdl01012018-badarudins-2164-1-coverdai.pdf

Buldur, A., \& Ömero, E. (2018). An Examination of the Relationship between Pre-school Children's and Their Teachers 'Attitudes and Awareness towards the Environment, 7(2), 221-229. https://doi.org/10.5539/jel.v7n2p221

Clark, K. E. (2012). Ecological Intelligence and Sustainability Education in Special Education, 3845.

Dick, W., Carey, L., \& Carey, J. (2015). The Systematic Design of Instruction. The United States of America: PEARSON.

Diposaptono, Subandono \& Budiman, F. A. (2009). Menyiasati perubahan iklim di wilayah pesisir dan pulau-pulau kecil. Penerbit Buku Ilmiah Populer.

Fugate, J. (2018). Assessment for Project-Based Courses James Fugate, 6(2), 153-161.

Hanney, R. (2018). Teaching in Higher Education Doing, being, becoming: a historical appraisal of the modalities of project-based learning modalities of project-based learning. Teaching in Higher Education, $\quad 0(0), \quad 1-15$. https://doi.org/10.1080/13562517.2017.1421628

IPCC. (2007). Global Warming of $1.5^{\circ} \mathrm{C}$. Retrieved from https://www.ipcc.ch/sr15/

Istiawati. (2016). Pendidikan Karakter Berbasis Nilai-Nilai Kearifan Lokal Adat Ammatoa dalam Menumbuhkan Karakter Konservasi. Cendikia, 10(1), 1-18.

Liang, W., \& Yang, M. (2018). Urbanization, Economic Growth, and Environmental Pollution: Evidence from China. Sustainable Computing: Informatics and Systems. https://doi.org/10.1016/j.suscom.2018.11.007

Quint, J., \& Condliffe, B. (2018). Project-Based Learning, (January).

Retnowati, R., \& Helena, G. (2018). kreativitas Dalam Pengembangan Model Pembelajaran. Bogor: Langit Arbiter.

Retnowati, R., Istiana, R., \& Suhardi, E. (2018). Pengembangan Model Pocket Book Berbasis Kekayaan Lokaldalam Peningkatan Perilaku Ramah Lingkungan Siswa SMA Negeri Kota Bogor. Jurnal Pendidikan Indonesia, 4(4), 1-6. Retrieved from http://www.jurnal.fkip.uns.ac.id/index.php/jpi/articl e/viewFile/12129/8643

Reza. (2017). 15 Permasalahan Lingkungan Hidup Indonesia dan Penyebabnya. Retrieved from Web Page website: https://materiips.com/permasalahanlingkungan-hidup

Rosidin, U., \& Suyatna, A. (2017). Teachers and Students Knowledge about Global Warming: a Study in Smoke Disaster Area of Indonesia, 12(4), 777-785.

Sart, G. (2014). The effects of the development of metacognition on project-based learning. Procedia Social and Behavioral Sciences, 152, 131-136. https://doi.org/10.1016/j.sbspro.2014.09.169

Setiawan, H. (2014). Pendugaan Cadangan Karbon Pada Ekosistem Hutan Hujan Tropis Dataran Rendah. In Mitigasi dan Adaptasi Perubahan Iklim Menuju Tata Kelola dan Hutan Lestari (pp. 161-168). Jakarta: Kementrian Kehutanan.

Sutrisno. (2005). Revolusi pendidikan di Indonesia: membedah metode dan teknik pendidikan berbasis kompetensi. Yogjakarta: AR-Ruzz Media Jogjakarta.

Taufik, \& Izdihar, H. (2017). Climate Change And Its Impact On Indonesian Food Security. International Academic Conference 20-21 April 2017.

Tripodi, N. (2018). SC. International Journal of Osteopathic Medicine. https://doi.org/10.1016/j.ijosm.2018.09.004

Troyer, J. A., Tost, J. R., Yoshimura, M., Lafontaine, S. D., \& Mabie, R. (2012). Teaching Students How to Meditate Can Improve Level of Consciousness and Problem Solving Ability. Procedia - Social and Behavioral Sciences, 69(Iceepsy), 153-161. https://doi.org/10.1016/j.sbspro.2012.11.394

Wihardjo, S. D., Hartati, S., Nurani, Y., \& Sujarwanta, A. 
(2017). The effects of green schooling knowledge level and intensity of parental guidance on the environmental awareness of the early age student, 12(5),

251-257. https://doi.org/10.5897/ERR2015.2608

Yoo, M., \& Park, J. (2014). Nurse Education Today Effect of case-based learning on the development of graduate nurses' problem-solving ability. YNEDT,
34(1),

$47-51$

https://doi.org/10.1016/j.nedt.2013.02.014

Yu, Y., Yang, X., \& Li, K. (2019). Effects of the terms and characteristics of cadres on environmental pollution : Evidence from 230 cities in China, 232(October 2018),

179-187. https://doi.org/10.1016/j.jenvman.2018.11.002 